\title{
NORMAL FASTING BLOOD SUGAR LEVELS AND MEDICATION ADHERENCE IMPROVE THE QUALITY OF LIFE OF TYPE 2 DIABETES MELLITUS PATIENTS IN PRIMARY HEALTH FACILITIES
}

\author{
TITIEK HIDAYATI ${ }^{1,4}$, SITI NUR FATIMAH ${ }^{2}$, SHELLY ISKANDAR ${ }^{3}$ \\ ${ }^{1}$ Department of Community and Family Medicine, Medical and Health Science Faculty, Universitas Muhammadiyah Yogyakarta, \\ Indonesia. ${ }^{2}$ Departement of Clinical Nutrition, Medical Faculty, Padjajaran University, Indonesia. ${ }^{3}$ Departement of Psichiatry, Medical \\ Faculty, Padjajaran University, Indonesia. ${ }^{4}$ Primary Care Medicine Program, Medical Faculty, Padjadjaran University, Indonesia. \\ Email: hidayatifkumy@yahoo.co.id
}

Received: 09 August 2018, Revised and Accepted: 01 October 2018

ABSTRACT

Objective: The aim of the overall study was to determine the quality of life (QOL) and the factors that influence it in patients with diabetes mellitus (DM) in primary health care (PHC) Jetis 1, Bantul.

Methods: This cross-sectional study was conducted on 153 DM patients in PHC Jetis I, Bantul. Respondents were recruited by inclusion and exclusion criteria. Primary data on exposure to cigarette smoke, adherence with physical activity, perception of disease, and QOL are collected through interviews. Data were analyzed by a mean test for ratio scale data and Chi-square test.

Results: The results showed that the QOL and the level of adherence of DM patients in Puskesmas Jetis I were classified as very good. Male patients, elementary school graduates, normal body mass index (BMI), normal fasting blood sugar levels, adherent DM medication, and positive disease perception have a greater chance of having a better QOL. The mean of the random blood sugar and the fasting blood sugar levels exceeded the normal values, with $261.70 \pm 121.15 \mathrm{mg} / \mathrm{dl}$ and $167.43 \pm 10.23$, respectively.

Conclusion: The QOL of DM patients in I Jetis PHC is very good. Men, normal BMI, adherent with medication therapy, and normal fasting sugar levels are associated with an increase in QOL.

Keywords: Quality of life, Diabetes mellitus, Adherence, Normal fasting blood sugar.

(C) 2018 The Authors. Published by Innovare Academic Sciences Pvt Ltd. This is an open access article under the CC BY license (http://creativecommons. org/licenses/by/4. 0/) DOI: http://dx.doi.org/10.22159/ajpcr.2018.v11i11.29006

\section{INTRODUCTION}

Health-related quality of life (HRQOL) is a concept that is often used as a basis for evaluating acute and chronic disease medication surveillance programs including diabetes mellitus (DM) [1]. The World Health Organization defines QOL as individual perceptions of values, concepts, and cultures in which they live and are interconnected to achieve life goals and expectations [2-4]. Although the measurement of the patient's QOL is subjective, HRQOL has been used as a method to evaluate the cost-effectiveness of therapy management. Assessment of the QOL of DM patients in primary health facilities in Indonesia has not become a priority, even though the patient's QOL data can be used as an indicator of management success and management evaluation of DM patients management at the Puskesmas (Indonesia's primary health facilities). In contrast to Indonesia, the quality-adjusted life year (QALY) assessment as one of the outcome parameters for DM management and the basis for policymaking in primary health facilities has been widely carried out in Asian and Southeast Asian countries [5] such as Malaysia [6] and Singapura [7].

The QOL reflects therapy success and supports disease management success. Study of DM patients' QOL in primary health facilities is important because DM is a chronic disease, with its increasing incidence, prevalence, treatment costs, and complications every year [8]. The IDF Diabetes Atlas/ADA latest report [9] estimates that currently there are 415 million people with diabetes with a prevalence of 2.8-4.4\%. The facts show that DM patients are susceptible to various complications $[10,11]$ and decreased QOL [12]. In Southeast Asia, by 2030 it is estimated that there will be 58.1 million people with more than $25 \%$ having less than the average QALY [13]. QALY assessment in DM patients needs to be done to achieve better governance to increase therapeutic success and decrease the complication incidence in Indonesia so that cost efficiency can be realized.

Chronic diseases, such as type 2 DM (T2DM), will cause medical, socioeconomic, and psychological problems that will limit the ability to engage in activities that will affect the QOL [14-18]. DM is a chronic disease characterized by an increase in blood sugar levels [19-22]. Uncontrolled blood sugar levels can cause acute or chronic complications $[20,23]$. T2DM requires long-term therapy to control blood sugar levels and prevent complications [24]. In addition, more than $50 \%$ of T2DM patients over the age of 65 experience functional disorders that affect their autonomy and QOL [25]. T2DM patients have been shown to have a higher risk for the incidence of nephropathy, retinopathy, hypertension, stroke, peripheral neuropathy, and heart failure due to their failure to control blood sugar levels [26]. In Indonesia, DM patients, in 2030, are estimated to reach 21.3 million people, $20-30 \%$ of them with uncontrolled blood sugar or therapy target not achieved.

The medication therapy targets (MTP) in T2DM not be met were not only caused by the inappropriate use of drugs but also by patients' lifestyle and psychosocial problems. Pharmacists need to consider the most common MTPs when counseling patients with T2DM [27].

Many factors can be attributed to the QOL of DM patients. Research in Singapore and Malaysia shows that distress, poor sleep quality, and comorbidity are associated with a decrease in DM patients' HRQOL [6,27-29]. It has been proven that controlled blood sugar levels 
are an important factor in maintaining the QOL of DM patients [30]. Research in Singapore and Indonesia shows that both hypoglycemia and hyperglycemia conditions are associated with a decrease in the QOL of DM patients [31,32]. Factors that play a role in failure of blood glucose control such as patients' medication adherence need to be considered in the care of DM patients in the primary health center (PHC) [33]. Blood glucose levels that are not appropriately controlled can cause both acute and chronic complications. As many as, $63.1 \%$ of patients with T2DM have a risk of developing hypertension complications. DM can trigger various complications and causes a decrease in QALY [34].

Non-adherence or nonconcordance in undergoing therapy is a problem that often occurs so that patients experience therapy failure [35] and decreased QOL [36]. Non-adherence can prolong the illness duration and severity [37-39]. Various studies have shown that patient adherence with chronic disease treatment is generally low at $50 \%$ or lower. Nonadherence can be caused by various factors such as lack of knowledge and understanding of drugs and the use of drugs for therapy [40,41], complexity of drug regimens, drug costs, age (increased age is inversely proportional to medication adherence), lack of family/social support, and cognitive problems in geriatrics. Other factors that have been shown to be related to adherence are perceptions about the disease and duration of illness and psychological factors such as awareness, drug safety, and tolerability [42]. Therapy results will not reach optimal levels without patients' awareness [43]. Several methods have been developed to assess therapeutic adherence. The self-report scale is generally used to assess adherence to the use of antidiabetic and antihypertensive drugs, and many have been modified for use in Indonesia [44-46]. The medication adherence rating scale (MARS) method is one of the methods of measuring adherence with tested validity and reliability and may be used in research in primary health facilities. Therefore, the relationship of blood sugar and therapy adherence with the QOL of T2DM patients in Puskesmas Jetis 1 Bantul needs to be examined.

\section{METHOD}

\section{Research design and subjects}

Thisstudy is an analytic observational study with a cross-sectional design of DM patients in Puskesmas Jetis 1, Bantul, Yogyakarta. Respondents were all T2DM patients who met the inclusion and exclusion criteria. Inclusion criteria included adult patients (1) both men and women aged 18 years or older, (2) diagnosed as DM patients who received medication at the study site during the study period, and (3) consensual to be the study subjects. This study excluded DM patients diagnosed with hearing loss, pregnancy, kidney disorders, complications or a history of comorbid TB, HIV AIDS, heart failure, coronary heart disease, endocrine disorders (hypothyroidism or hyperthyroidism), chronic musculoskeletal disorders, or mental disorders.

Research protocols and inform consent forms were reviewed by the Medical and Health Science Faculty, Universitas Muhammadiyah Yogyakarta health research Ethics Committee and have received ethical clearance. This research has also obtained research permission from the Bantul Regency Regional Development Planning Agency (BAPPEDA).

\section{Sample size}

The number of all T2DM patients in Jetis I PHC based on the database was 216. The sample size is calculated with the Lemeshow formula below:

$$
\begin{aligned}
& n=\left(\frac{Z \square+Z \square}{\operatorname{InOR}}\right)^{2} \square \frac{1}{P x(1 \square P x) P y(1 \square P y)} \\
& n=\left(\frac{1.96+0.84}{\operatorname{In} 2.8}\right)^{2} \square \frac{1}{0.5(0.5) 0.5(0.5)}
\end{aligned}
$$

wherein $=$ sample size, $\mathrm{Za}=$ standard deviates from type I errors $=1.96$, $\mathrm{Zb}=$ standard deviates from type II errors $=0.84$ and $\mathrm{OR}=$ Minimum odds ratio that is considered significant $=2.8$, where $\mathrm{Px}=$ proportion of exposure or proportion of risk factors $=0.5$ and $\mathrm{Py}=$ proportion of effects or proportions of dependent variables $=0.5$. Based on the results of the calculations, the number of samples involved was 120 patients.

\section{Data types and sources}

The type of data in this study is primary and secondary data. Primary data were obtained through interviews using structured and observational questionnaires or laboratory examinations, while secondary data were collected from medical records. Primary data include life habits (exercise, medication adherence, QOL, type of work, education history, and marital status). Another primary data are fasting blood sugar levels obtained through laboratory examination. Secondary data include DM diagnosis in medical records, illness history, and treatment history in the past 3 months and clinical manifestations that occur.

\section{Research variables and operational definitions}

Variables in this study include independent variables, namely clinical outcomes (fasting blood sugar levels and blood pressure), medication adherence, exposure to cigarette smoke, anti-DM drugs, and comorbid diseases and the dependent variables include patients' QOL using the SF-36 questionnaire form.

\section{Operational variable definition}

The independent variables in this study were blood sugar levels, medication adherence, and exposure to cigarette smoke. The dependent variable in the study is the patients' QOL. The preparation of operational variable definitions is done to determine the appropriate data collection tool [47] (Table 1)

\section{Research instruments and procedures}

\section{Research instruments}

Questionnaire

Questionnaires used in this study include: (1) Respondents' characteristics questionnaire to obtain primary data from patients in the form of demographic data (education, marital status, and occupation) and life habits (smoking and exercise), (2) MARS questionnaire to assess patient adherence in undergoing anti-DM drug therapy, and (3) SF-36 questionnaire to assess the patient's QOL. The SF-36, whose Indonesian version has been validated, is an instrument that has been used in various countries and used as a gold standard in assessing QOL because this instrument consists of 36 short questions covering various aspects, namely physical, emotional, social, physical health, emotional health, pain, fatigue, and general health aspects. Physical components consist of physical function, physical role, pain, and general health, while the mental component consists of the role of emotions, vitality, social function, and mental health. This questionnaire has three stages: Scoring, the average of each domain, and grouping components by domain. The average score range is $0-100$ with a normative average score of 50 [48]. The validity and reliability of the SF-36 questionnaire were tested, and the results showed that this questionnaire could be used to measure QOL [49].

\section{Data collection form}

Data collection form is used to collect data taken from medical records or patient status which includes name, age, gender, hospital diagnosis data, treatment, and laboratory data.

\section{Research procedure}

The research procedure is divided into three stages, namely preparation, implementation, and end. (1). Preparation phase: In the first stage, the researcher took care of the licensing at the BAPPEDA, collected secondary data (including general description of Jetis 1 PHC, Bantul in Yogyakarta, number of visits, diabetes incidence from medical records, and other sources), developed protocols on filling out questionnaires and data collection forms and prepared supporting facilities and infrastructure (writing facilities, etc.). Data collectors were trained on how to use 
Table 1: Variables operational definitions and measurement scales

\begin{tabular}{|c|c|c|c|c|}
\hline No & Variables & Operational definitions & Measurement Categories & Scales \\
\hline 1 & Education & $\begin{array}{l}\text { Information on patients' education levels obtained from interviews } \\
\text { or health questionnaire. The levels are no school/elementary } \\
\text { school (SD), junior high school (SMP), senior high school (SMA), DI, } \\
\text { DIII, S1, S2, S3, and others. }\end{array}$ & $\begin{array}{l}1=\text { No school } / \mathrm{SD} \\
2=\mathrm{SMP} ; 3=\mathrm{SMA} 4=\mathrm{D} 1-\mathrm{S} 1 ; 5=\mathrm{S} 2\end{array}$ & Ordinal \\
\hline 2 & Profession & $\begin{array}{l}\text { Information on the patients' type of work or profession in earning } \\
\text { a living obtained from interviews or health questionnaire, } \\
\text { categorized as employed or unemployed. }\end{array}$ & $\begin{array}{l}\text { 1=Employed } \\
\text { 2=Unemployed }\end{array}$ & Nominal \\
\hline 6 & Cigarette exposure & $\begin{array}{l}\text { Active smokers, namely patients who are currently smoking and } \\
\text { have smoked at least } 100 \text { cigarettes ( } 3-4 \text { packs) in their lifetime, or } \\
\text { passive smokers, namely patients who do not smoke but there are } \\
\text { active smokers in their homes }\end{array}$ & $\begin{array}{l}\text { 1. Not exposed } \\
\text { 2. Exposed }\end{array}$ & Nominal \\
\hline 7 & Adherence & $\begin{array}{l}\text { Measured with the MARS questionnaire with the highest score of } \\
25 \text { and lowest of } 0 \text {. The average adherence score is measured and } \\
\text { then compiled in the following adherence ratings: } \\
\text { 1. High adherence: } 21-25 \\
\text { 2. Moderate adherence: } 16-20 \\
\text { 3. Low adherence: }<16 \\
\text { The scale used to measure the level of adherence is an ordinal scale. }\end{array}$ & $\begin{array}{l}\text { Adherence levels: } \\
\text { 1.High adherence } \\
\text { 2.Low adherence }\end{array}$ & nominal \\
\hline 8 & $\begin{array}{l}\text { QOL } \\
\text { SF-36 }\end{array}$ & $\begin{array}{l}\text { QOL is a state of well-being which is a combination of two } \\
\text { components: The ability to carry out daily activities (reflecting } \\
\text { physical function, emotional function, social function, physical } \\
\text { condition, emotional state, pain, fatigue, and general health) } \\
\text { and patient satisfaction at the levels of function and disease } \\
\text { control (Gotay et al., 1992). The SF-36 is an instrument used to } \\
\text { measure QOL with } 36 \text { short questions and } 8 \text { health domains and is } \\
\text { available in the Indonesian version. } \\
\text { QOL scores are then classified into } 4 \text { : Low, adequate, good, and } \\
\text { very good. } 1=\text { Low }(0-25) ; 2=\text { Adequate }(26-50) ; 3=\text { Good (51-75); } \\
4=\text { Very good (76-100). QOL is then categorized as good or not } \\
\text { good. }\end{array}$ & $\begin{array}{l}\text { 1.Good QOL (score }>75) \\
\text { 2. Not good QOL (score }<75 \text { or }=75)\end{array}$ & nominal \\
\hline 9 & Age & $\begin{array}{l}\text { The age of DM patients is obtained from medical record or } \\
\text { interview results and is classified into } 2: 18-65 \text { years and }>65 \text { years. }\end{array}$ & $\begin{array}{l}1=\text { Aged }<65 \text { tahun } \\
2=\text { Aged } \geq 65 \text { tahun }\end{array}$ & Ordinal \\
\hline
\end{tabular}

DM: Diabetes mellitus

questionnaires and data collection forms. (2) Implementation phase: This stage begins with subject recruitment, namely patients who are positively diagnosed with diabetes that meet the inclusion criteria. Prospective subjects then received an explanation of the purpose and benefits of the study. Patients who agreed to be the subject were asked to give a sign of approval by signing an informed consent form. Subsequently, the patient was interviewed, and the researcher filled out data recording forms, health assessment forms (patients' demographic data) and data collection forms containing diagnoses, laboratory results, blood pressure, and medicines listed in the prescription. Following that, interviews were conducted to obtain data for the lifestyle questionnaire, treatment history, adherence questionnaire, and QOL questionnaire (3). The final stage: At this stage data analysis, report preparation, preparation of publication texts, and dissemination of results are carried out.

\section{Data analysis}

Univariate analysis was used to obtain an overview of the frequency distribution (proportion) of patients' characteristics based on demographics and Chi-square test to determine the relationship between independent variables, namely age, body mass index (BMI), adherence, fasting sugar levels, and smoking status with patients' QOL.

\section{RESULTS AND DISCUSSION}

\section{Respondents' characteristics}

There were 153 DM patients in Jetis I PHC involved in the study. Their characteristics are presented in Table 2.

Table 2 shows that most of the respondents were women, aged over 45 years, and had elementary school education. Clinical characteristics of DM patients at Jetis I PHC are presented in Table 3.
Table 3 shows that most DM patients in the PHC suffer from comorbidities between 1 and 4 types of disease. Hypertension is the most common comorbid disease found in 58 patients followed by dyslipidemia in 18 patients. Metformin is the most widely prescribed anti-DM drug for patients with $58.17 \%$, followed by a combination of metformin and glimepiride with $32.68 \%$.

Description of the patients' clinical characteristics based on fasting blood sugar levels, medication adherence, and QOL

An overview of the DM patients' clinical condition in I JetisPHC is presented in Table 4.

Table 4 shows that the average age of the patient was 57.39 years and the mean of the random blood sugar and the fasting blood sugar levels exceeded the normal values, with $261.70 \pm 121.15 \mathrm{mg} / \mathrm{dl}$ and $167.43 \pm$ 10.23 , respectively. Other clinical parameters are within normal limits. The average adherence score of $22.44 \pm 2.99$ was classified as adherent, and the average QOL of $73.81 \pm 12.40$ was categorized as good QOL (score range 51-75). Furthermore, the mean score of patients' perceptions of DM can be categorized as good because it was $<40$.

Description of medication adherence behavior and QOL of patients Patients' distribution based on the level of adherence is presented in Table 5 .

Table 5 indicates that most of the patients were adherent (80.39\%), with a small proportion less and non-adherent. It is also known that most patients had a very good QOL (52.94\%), followed by good QOL (41.83\%) and relatively low QOL (5.23\%).

Bivariate analysis of factors associated with QOL

Table 6 shows the analysis results of the relationship between demographic factors (age), clinical output (normal fasting glucose 
Tabel 2: Distribution of demographic characteristics of DM patients in Jetis I PHC, Bantul, Yogyakarta

\begin{tabular}{|c|c|}
\hline Characteristic of DM patients & Frequency (\%) \\
\hline \multicolumn{2}{|l|}{ Sex } \\
\hline Male & $49(32)$ \\
\hline Female & $104(68)$ \\
\hline \multicolumn{2}{|l|}{ Marital status } \\
\hline Married & $153(100)$ \\
\hline Not married & $0(0)$ \\
\hline \multicolumn{2}{|l|}{ Age group (year) } \\
\hline$\leq 45$ & $12(7.85)$ \\
\hline $46-64$ & $112(73.20)$ \\
\hline$\geq 65$ & $29(18.95)$ \\
\hline \multicolumn{2}{|l|}{ Educational } \\
\hline Elementary school & $90(58.8)$ \\
\hline Junior high school & $21(13.7)$ \\
\hline Senior high school & $25(16.3)$ \\
\hline University & $17(11.1)$ \\
\hline \multicolumn{2}{|l|}{ Employment type } \\
\hline Civil servants-retirees & $22(14.4)$ \\
\hline Private-entrepreneur & $29(19)$ \\
\hline Housewife & $45(29.4)$ \\
\hline Farmer & $8(5.2)$ \\
\hline Laborer & $25(16.3)$ \\
\hline Unemployment & $24(15.7)$ \\
\hline \multicolumn{2}{|l|}{ Health assurance } \\
\hline BPJS & $124(81)$ \\
\hline Others & $29(19)$ \\
\hline \multicolumn{2}{|l|}{ Exercises habit } \\
\hline Yes & $61(39.9)$ \\
\hline No & $92(60.9)$ \\
\hline \multicolumn{2}{|l|}{ Tobacco smoke exposure } \\
\hline Yes & $26(17)$ \\
\hline No & $127(83)$ \\
\hline \multicolumn{2}{|l|}{ Diet } \\
\hline Yes & $131(85.6)$ \\
\hline No & $22(14.4)$ \\
\hline
\end{tabular}

Table 3: Distribution of Subject's clinical characteristic (illness duration, presence of comorbidities, type and number of comorbidities and medications received by DM patients) at I Jetis PHC, Bantul, DI Yogyakarta

\begin{tabular}{ll}
\hline Clinical characteristic & Frequency (\%) \\
\hline Disease duration (year) & \\
$1-5$ & $77(50.3)$ \\
$6-10$ & $34(27.2)$ \\
$>10$ & $42(27.5)$ \\
Comorbidity status & \\
No & $62(40.52)$ \\
Yes & $91(59.48)$ \\
Comorbidity type & \\
No comorbidity & $62(31.8)$ \\
Hypertension & $57(29.2)$ \\
Hypertension+dyslipidemic & $18(9.2)$ \\
Hypertension+gout & $7(3.6)$ \\
Hypertension+asthma & $5(2.6)$ \\
Others & $4(2.1)$ \\
Comorbidity number & \\
No comorbidity & $62(31.8)$ \\
1 comorbidity & $68(34.9)$ \\
2 comorbidity & $19(9.7)$ \\
$\geq 3$ comorbidity & $4(2.0)$ \\
Anti-DM drug & \\
Metformin & $89(58.17)$ \\
Metformin+glimepiride & $50(32.68)$ \\
metformmin+glibenklamid & $4(2.61)$ \\
Glimepiride & $4(2.61)$ \\
Metformin+insulin & $6(3.92)$ \\
\hline DM: Diabetes mellitus &
\end{tabular}

Table 4: Description of the demographic and clinical condition of DM patients ( $n=153)$ at I Jetis PHC, Bantul, DIY

\begin{tabular}{llll}
\hline Clinical Characteristic & Unit & Mean \pm SD & Min-max \\
\hline Age & Year & $57.39 \pm 8.27$ & $34-83$ \\
BMI & $\mathrm{Kg} / \mathrm{m}^{2}$ & $22.90 \pm 2.00$ & $15-33$ \\
Fasting glucose level & $\mathrm{mmHg}$ & $167.43 \pm 10.23$ & $40-330$ \\
Random glucose blood level & $\mathrm{mg} / \mathrm{dl}$ & $261.70 \pm 121.15^{*}$ & $82-637$ \\
Compliment score & & $22.44 \pm 2.99$ & $0-25$ \\
HRQALY score & & $73.81 \pm 12.40$ & $0-100$ \\
\hline
\end{tabular}

DM: Diabetes mellitus

Table 5: Distribution of level of complience and QAL of DM patients in Jetis I PHC, Bantul DIY

\begin{tabular}{lll}
\hline Variable & Frekuensi & Persentase \\
\hline Level of complient & & \\
Obey & 123 & 80.39 \\
semi-obedient & 25 & 16.34 \\
not obedient & 5 & 3.27 \\
Level of QOL & & \\
pretty good (QALY score=26-50) & 8 & 5.23 \\
Good (QALY score=51-75) & 64 & 41.83 \\
Very good ( QALY score=76-100) & 81 & 52.94 \\
Total & 153 & 100 \\
\hline
\end{tabular}

DM: Diabetes mellitus

level), BMI, compliance level, and status of smoke exposure with patients' QOL (QALY) status.

Table 6 indicates the factors associated with the very good QOL. Male, higher than elementary school education, and employed tend to increase the chances of having a very good QOL for respondents $(\mathrm{p}<0.05)$. In addition, BMI that is $\leq 25$ is associated with very good QOL with an odds ratio (OR) of 2.17 (confidence interval [CI]: 1.02-4.60; $\mathrm{p}=0.04$ ). Furthermore, fasting blood sugar levels and the number of single anti-DM drugs were associated with a very good QOL with an OR of 4.28 (CI 95\%: 1.77-10.35; $\mathrm{p}=0.001$ ) and 1.89 (CI 95\%: 1.00-3.65; $\mathrm{p}=0.04$ ). Medication adherence with anti-DM drugs has been shown to be associated with QOL with an OR of 2.2 (CI 95\%: 1.1-4.42; $\mathrm{p}=0.02$ ).

\section{DISCUSSION}

Based on the results of this study, T2DM patients' QOL is influenced by many factors, namely (1) the pathobiological condition and DM degree or type, (2) comorbidity, (3) distress level, (4) anti-DM drugs and medication adherence, (5) lifestyle (exercise/physical activity habits, smoking), and (6) patient's perception of DM. Other influencing factors include (a) age, because most patients are adults over the age of 40 and insulin resistance in type 2 diabetes tends to increase at the age of 40-65 years; (b) gender, because the QOL of women and men is different, where women generally have a lower QOL; and (c) level of education, because this is closely related to the processing of knowledge and information obtained. Education is an important factor in T2DM patients to be able to understand and manage independently; (d) socioeconomic status, because this is related to income, where low status can be a predictor of the patients' low QOL; (e) duration of illness, because this is related to the level of anxiety that can lower the patient's QOL; and (f) complications due to DM, both acute and chronic complications are serious problems because they can increase patients' physical, psychological and social disability, and ultimately can affect patients' QOL [36,50-55]. Al-Qasem et al. suggested that in addition to demographic factors (age, gender, and socioeconomic status), comorbidity and perception of disease, treatment regimen complexity also affects the patients' QOL $[39,56]$.

Patients' medication adherence and QOL

The results of the univariate analysis revealed that most patients were very adherent in undergoing anti-DM drug therapy, and the results of the 
Table 6: Factors related to the QOL of DM patients in I Jetis PHC, Bantul, DIY

\begin{tabular}{|c|c|c|c|}
\hline \multirow[t]{2}{*}{ Parameter } & \multicolumn{2}{|l|}{ QOL status } & \multirow[t]{2}{*}{ OR (CI 95\%; p) } \\
\hline & Very good & Pretty good & \\
\hline Age $\leq 60$ tahun & $58(71.6) / 23(28.4)$ & $44(61.1) / 28(38.9)$ & $1.61(0.82-3.16 ; 0.17)$ \\
\hline $\mathrm{BMI} \leq 25$ & $61(80.3) / 15$ (19.7) & $45(65.2) / 24(34.8)$ & $2.17(1.02-4.60 ; 0.04)^{*}$ \\
\hline Normal fasting glucose level & $73(90.1) / 8(9.9)$ & $49(68.1) / 23(31.9)$ & $4.28(1.77-10.35 ; 0.001)^{*}$ \\
\hline Good compliance & $62(76.5) / 19(23.5)$ & $43(59.7) / 29(40.3)$ & $2.2(1.1-4.42 ; 0.02)^{*}$ \\
\hline
\end{tabular}

DM: Diabetes mellitus, OR: Odds ratio, CI: Confidence interval

bivariate analysis showed that the patients' adherence was associated to their QOL. Adherence to treatment regimens is generally defined more broadly to describe how patients use prescription drugs. The word adherence is much preferred by many health workers because the word compliance giving the impression that the patient follows the doctor's instructions passively and the treatment plan is determined unilaterally by the doctor [41-44]. Dulmen et al. [4] defined medication adherence as a level of behavior in which patients use drugs and adhere to all the rules and advice recommended by health workers. The concept of adherence is often used in chronic diseases. There are various important terms to describe patient adherence, namely compliance is the patient's behavior to follow what is recommended or requested by a doctor or health worker. The concept of compliance feels negative because it is similar to the attitude of being obedient or submitting to the direction of a health worker. In contrast, adherence is based on patients' awareness that arises based on commitment, principles, and trust. Concordance is compliance that is formed as a result of discussions between patients and health workers or doctors to form an agreement or cooperation in taking treatment measures [52,53]. The concept of adherence is preferred by many health workers because compliance gives the impression that the patient follows the doctor's instructions passively and the treatment plan is determined unilaterally by the doctor [54]. Factors that can influence the level of patient adherence have been identified in several studies. Sabaté (2003) claimed that adherence will increase with clear treatment instructions, individual beliefs and attitudes to heal, pleasant and authoritative health workers, social and family support, knowledge, minimum drug effects, simple treatment, affordable prices, and good relationships between health workers and patients $[40,55]$. In general, the factors related to the level of adherence in DM patients are age, education, patient knowledge about drugs and disease, social and economic status, therapeutic regimens, and patient interactions with health workers [56,57].

\section{CONCLUSION}

DM patients in Jetis I PHC, Bantul, have good QOL. Patients' controlled fasting blood sugar levels and medication adherence in undergoing anti-DM drug therapy can increase the patients' chance of having a good QOL.

\section{FINANCIAL SUPPORT AND SPONSORSHIP}

Nil.

\section{AUTHORS CONTRIBUTION}

TH conceived the study. TH, SF, and SI designed the research. TH performed the analysis and wrote the manuscript. SF and SI interpreted the results and contributed to the discussion. All authors read and approved the final manuscript.

\section{CONFLICTS OF INTEREST}

All authors declare that they have no conflicts of interest.

\section{REFERENCES}

1. Esser A, Gube M, Schettgen T, Kraus T, Lang J. QALY as evaluation tool in a health surveillance program. Int J Hyg Environ Health
2014;217:399-404

2. Akrom SG, Darmawan E. Improving Outpatient's Quality of Life via Patient Adherence of Antihypertensive Therapy Using "Mobile Phone (SMS) and Brief Counseling5A" in Polyclinic of Internal Medicine at PKU Muhammadiyah Bantul Hospital. Yogyakarta: Jurnal Farmasi Klinik Indonesia.

3. Trikkalinou A, Papazafiropoulou AK, Melidonis A. Type 2 diabetes and quality of life. World J Diabetes 2017;8:120-9.

4. Grandy S, Chapman RH, Fox KM, SHIELD Study Group. Quality of life and depression of people living with Type 2 diabetes mellitus and those at low and high risk for Type 2 diabetes: Findings from the study to help improve early evaluation and management of risk factors leading to diabetes (SHIELD). Int J Clin Pract 2008;62:562-8.

5. Jiao F, Wong CKH, Gangwani R, Tan KCB, Tang SCW, Lam CLK, et al. Health-related quality of life and health preference of chinese patients with diabetes mellitus managed in primary care and secondary care setting: Decrements associated with individual complication and number of complications. Health Qual Life Outcomes 2017;15:125.

6. Chew BH, Mohd-Sidik S, Shariff-Ghazali S. Negative effects of diabetes-related distress on health-related quality of life: An evaluation among the adult patients with Type 2 diabetes mellitus in three primary healthcare clinics in Malaysia. Health Qual Life Outcomes 2015;13:187.

7. Laxy M, Hunger M, Thorand B, Meisinger C, Kirchberger I, Holle R, et al. The intermediate burden of diabetes mellitus in patients with cardiovascular disease (Cvd): A Quality adjusted life year (Qaly) - Analysis based on primary longitudinal data. Value Health 2014;17:A494

8. Schwappach DL. Resource allocation, social values and the QALY: A review of the debate and empirical evidence. Health Expect 2002;5:210-22.

9. International Diabetes Federation. Diabetes Atlas. $6^{\text {th }}$ ed. Belize: NAC, Bruss Belg International Diabetes; 2015.

10. World Health Organization. Global Health Risks-Mortality and Burden of Disease Attributable to Selected Major Risks. Geneva: World Health Organization; 2017.

11. American Diabetes Association. (2) classification and diagnosis of diabetes. Diabetes Care 2015;38 Suppl: S8-16.

12. Clark M. Adherence to treatment in patients with Type 2 diabetes. J Diabetes Nurs 2004;8;386-91.

13. Rahman MS, Akter S, Abe SK, Islam MR, Mondal MN, Rahman JA, et al. Awareness, treatment, and control of diabetes in Bangladesh: A nationwide population-based study. PLoS One 2015;10:e118365.

14. Amelia R, Lelo A, Lindarto D, Mutiara E. Quality of Life and Glycemic Profile of Type 2 Diabetes Mellitus Patients of Indonesian: A Descriptive Study. In: IOP Conference Series: Earth and Environmental Science. IOP Publishing; 2018. p. 12171.

15. Kesehatan DR. Riset Kesehatan Dasar. Jakarta: Badan Penelit Dan Pengemb Kesehat Dep Kesehat Repub Indones; 2013

16. IDF. The Metabolic Syndrome. Int Diabetes Fed.

17. Hossain P, Kawar B, El Nahas M. Obesity and diabetes in the developing world - a growing challenge. N Engl J Med 2007;356:213-5.

18. Yogyakarta PK. Profil Kesehatan Tahun 2015 Kota Yogyakarta. Yogyakarta: Yogyak Dinas Kesehatan Kota; 2015. p. 15.

19. Bantul DK. Profil Kesehatan Kabupaten Bantul. Yogyakarta: Yogyak Dir Jenderal Pelayanan Med; 2010.

20. Akrom A. Factors relate to the hypercreatininemia event of patients at the risk of metabolic syndrome in Jetis I public health center. Pharm 2017;7:6717.

21. Jellinger PS. Metabolic consequences of hyperglycemia and insulin resistance. Clin Cornerstone 2007;8 Suppl 7:S30-42.

22. Grandy S, Fox KM. EQ-5D visual analog scale and utility index values in individuals with diabetes and at risk for diabetes: Findings from the study to help improve early evaluation and management of risk factors 
leading to diabetes (SHIELD). Health Qual Life Outcomes 2008;6:18

23. Danaei G, Finucane MM, Lu Y, Singh GM, Cowan MJ, Paciorek CJ, et al. National, regional, and global trends in fasting plasma glucose and diabetes prevalence since 1980: Systematic analysis of health examination surveys and epidemiological studies with 370 countryyears and $2 \cdot 7$ million participants. Lancet 2011;378:31-40.

24. Infodatin. Watch out for Diabetes, Eat Well, Life Well. Jakarta: Ministry of Health Republic of Indonesia; 2014.

25. Peña-Longobardo LM, Rodríguez-Sánchez B, Mata-Cases $M$, Rodríguez-Mañas L, Capel M, Oliva-Moreno J, et al. Is quality of life different between diabetic and non-diabetic people? The importance of cardiovascular risks. PLoS One 2017;12:e189505.

26. Hemmingsen B, Gimenez-Perez G, Mauricio D, Roqué I Figuls M, Metzendorf MI, Richter B, et al. Diet, physical activity or both for prevention or delay of Type 2 diabetes mellitus and its associated complications in people at increased risk of developing Type 2 diabetes mellitus. Cochrane Database Syst Rev 2017;12:CD003054.

27. Wahyuningrum R, Wahyono J, Mustofa M, Prabandari YS, A qualitative study discovering the common medication-therapy problems in patients with Type 2 diabetes mellitus (t2dm) in Indonesia. Asian J Pharm Clin Res 2017;10:246-50

28. Siddiqui AN, Khayyam KU, Siddiqui N, Sarin R, Sharma M. Diabetes prevalence and its impact on health-related quality of life in tuberculosis patients. Trop Med Int Health 2017;22:1394-404.

29. Nuworza K. Illness Perception, Religiosity and Mental Health of Diabetic Patients in Ghana [PhD Thesis]. University of Ghana; 2013.

30. Indrayana S, Guo SE, Lin CL, Fang SY. Illness perception as a predictor of foot care behavior among people with Type 2 diabetes mellitus in Indonesia. J Transcult Nurs 2018;1:1-9.

31. Perwitasari DA, Santosa SB, Faridah IN, Kaptein AA. Illness perceptions and quality of life in patients with diabetes mellitus Type 2 . Indones J Clin Pharm 2017;6:190-9.

32. Sheu WH, Ji LN, Nitiyanant W, Baik SH, Yin D, Mavros P, et al. Hypoglycemia is associated with increased worry and lower quality of life among patients with Type 2 diabetes treated with oral antihyperglycemic agents in the Asia-Pacific region. Diabetes Res Clin Pract 2012;96:141-8.

33. Nasution A, Simbolon RC, Tanjung HR. Characteristics, antihyperglycemics utilization, and quality of life in patients with Type 2 diabetes mellitus admitted to a primary health center. Indones J Pharm Clin Res 2018;1:1-10

34. Suppapitiporn S, Chindavijak B, Onsanit S. Effect of diabetes drug counseling by pharmacist, diabetic disease booklet and special medication containers on glycemic control of Type 2 diabetes mellitus: a randomized controlled trial. J Med Assoc Thai 2005;88:S134-41.

35. Mogensen CE, Neldam S, Tikkanen I, Oren S, Viskoper R, Watts RW, et al. Randomised controlled trial of dual blockade of renin-angiotensin system in patients with hypertension, microalbuminuria, and non-insulin dependent diabetes: The candesartan and lisinopril microalbuminuria (CALM) study. BMJ 2000;321:1440-4.

36. Franciosi M, Lucisano G, Pellegrini F, Cantarello A, Consoli A, Cucco L, et al. ROSES: Role of self-monitoring of blood glucose and intensive education in patients with Type 2 diabetes not receiving insulin. A pilot randomized clinical trial. Diabet Med 2011;28:789-96.

37. Indonesian Endocrinology Association. Consensus of Prevention and Management of Type 2 Diabetes Melitus in Indonesia 2011. Executive Board of the Indonesian Endocrinology Association (PB PERKENI); 2011.

38. Borgsteede SD, Westerman MJ, Kok IL, Meeuse JC, de Vries TP, Hugtenburg JG, et al. Factors related to high and low levels of drug adherence according to patients with Type 2 diabetes. Int J Clin Pharm
2011;33:779-87.

39. Al-Qasem A, Smith F, Clifford S. Adherence to medication among chronic patients in Middle Eastern countries: Review of studies. East Mediterr Health J 2011;17:356-63.

40. Sabaté E. Adherence to Long-Term Therapies: Evidence for Action. Geneva, Switzerland: World Health Organization; 2003.

41. Wabe NT, Angamo MT, Hussein S. Medication adherence in diabetes mellitus and self management practices among Type-2 diabetics in Ethiopia. N Am J Med Sci 2011;3:418-23.

42. KemenKes RI. Riset Kesehatan Dasar (Riskesdas). Jkt Badan Litbangkes DepKes RI Tersedia. Available from: https://wwwK4health OrgsitesdefaultfileslaporanNasional20Riskesdas2007.

43. Spasić A, Radovanović RV, Djordjević AC, Stefanović N, Cvetković T. Quality of life in Type 2 diabetic patients. Acta Fac Med Naissensis 2014:31:193-200

44. Younis BB, Arshad R, Yousuf H, Salman F, Masood J, Khurshid S, et al. Impact of Type 2 diabetes mellitus on quality of life in people with diabetespresenting to a specialist diabetes clinic. Turk J Med Sci 2017;47:123-6.

45. Morisky DE, Ang A, Krousel-Wood M, Ward HJ. Predictive validity of a medication adherence measure in an outpatient setting. J Clin Hypertens (Greenwich) 2008;10:348-54 .

46. Sakthong P, Chabunthom R, Charoenvisuthiwongs R. Psychometric properties of the Thai version of the 8-item morisky medication adherence scale in patients with Type 2 diabetes. Ann Pharmacother 2009;43:950-7.

47. Saputri GZ, Akrom A, Darmawan E. Improving outpatient's quality of life through patient adherence of antihypertensive therapy using mobile phone (SMS) and brief counseling-5A in polyclinic of internal medicine at pku muhammadiyah bantul hospital, Yogyakarta. Indones J Clin Pharm 2017;6:67-77.

48. Corea G. Need for Change: Towards the New International Economic Order. Korea: Elsevier; 2014

49. Wen CP, Wai JP, Tsai MK, Yang YC, Cheng TY, Lee MC, et al. Minimum amount of physical activity for reduced mortality and extended life expectancy: A prospective cohort study. Lancet 2011;378:1244-53.

50. Dede ND, Ipekci S, Kebapcilar L, Arslan M, Kurban S, Yildiz M, et al. Effect of Aerobic Exercise Training on Serum Malondialdehyde Level and Quality of Life in Type 2 Diabetes. In: $20^{\text {th }}$ European Congress of Endocrinology. BioScientifica; 2018.

51. Ware JE Jr. SF-36 health survey update. Spine (Phila Pa 1976) 2000;25:3130-9

52. van Dulmen S, Sluijs E, van Dijk L, de Ridder D, Heerdink R, Bensing J, et al. Patient adherence to medical treatment: A review of reviews. BMC Health Serv Res 2007;7:55.

53. Osterberg L, Blaschke T. Adherence to medication. N Engl J Med 2005;353:487-97.

54. Zyoud SH, Al-Jabi SW, Sweileh WM, Morisky DE. Relationship of treatment satisfaction to medication adherence: Findings from a crosssectional survey among hypertensive patients in Palestine. Health Qual Life Outcomes 2013;11:191

55. Butt M, Ali AM, Bakry MM, Health-related quality of life in poorly controlled Type 2 diabetes patients-association of patients' characteristic with EQ-5D domain, mean EQ-5D scores, and visual analog scale score. Asian J Pharm Clin Res 2018;11:93-8

56. Bernard HR. Research Methods in Anthropology: Qualitative and Quantitative Approaches. Lantham, MD: Rowman and Littlefield; 2017.

57. Saputri GZ, Dini AS. Validation of behaviour measurement instrument of patients with diabetes mellitus and hypertension. Mater Sci Eng 2017;259:12014. 